\title{
Seasonal changes in activity of some enzymes in the European bison Bison bonasus
}

\author{
Janusz GILL
}

Gill J. 1992. Seasonal changes in activity of some enzymes in the European bison Bison bonasus. Acta theriol. 37: $291-300$.

The metabolic activity of the European bison, Bison bonasus (Linnaeus, 1758) is rather low, but it was shown that it possess the ability to adapt its metabolism to environmental factors, mostly to approaching winter. In 251 European bison of four age and sex groups seasonal changes in the activity of aldolase, acid and alkaline phosphatases, aspartate and alanine aminotransferases were studied. The seasonal cyclicity was found only in aspartate aminotransferase activity in all groups. In the aldolase activity the seasonal cycles were found in young females and in mature bison. Circannual changes were found in the acid phosphatase activity only in mature bison. The same was shown in the activity of alanine aminotransferase. Seasonal cyclicity was found in the alkaline phosphatase activity in males (young and mature). Ten out of 13 acrophases of cyclic indices occurred in the period from the beginning of September till mid-March, i.e. during cold time of the year. This indicates that at this period the bison's metabolism is adapted to cold weather.

Department of Vertebrate Animal Physiology, Zoological Institute, University of Warsaw, Zwirki i Wigury 93, 02-089 Warsaw, Poland

Key words: Bison bonasus, aldolase, acid and alkaline phosphatases, aspartate and alanine aminotransferases, seasonal cyclicity

\section{Introduction}

The role of many enzymes in domesticated ruminants has been described in many papers (Białkowski et al. 1988, Bogin et al. 1977, Brown and Stallcup 1985, Peter et al. 1987). In previous papers I have shown seasonal adaptative changes with the features of circannual cyclicity in the indices of European bison Bison bonasus (Linnaeus, 1758) metabolism. They have been found in transporting system of the blood (RBC system, Gill 1989a) as well as in the end products of metabolism (lactic and pyruvic acids, Gill 1990). So, it was interesting to examine factors which function between those two groups of metabolic constituenes, i.e. activity of some enzymes available in the peripheral blood.

I have choosen 5 enzymes, 3 of them broadly involved in the carbohydrate metabolism (aldolase, acid and alkaline phosphatases) and 2 connected mostly with protein metabolism: aspartate aminotransferase and alanine aminotransferase. 


\section{Material and methods}

All the examined European bison were selected for the breeding aims from the free-ranging herd in Białowieża Primeval Forest ( $\mathrm{a}$ few were bred in reserves) and shot during the period from 1977 to 1990. Selection was made each month, except May and August, but in the case of young bison, except May, June, July and August. All 251 European bison were divided into four groups: Group 1, sexually immature males, $0-3$ years old; Group 2, immature females, $0-3$ years old; Group 3, mature bulls, over 3 years of age; Group 4, mature cows, over 3 years of age.

The blood was taken from the jugular vein cut immediately after the animal was shot. That procedure between the opening a vein and taking the blood lasted $2-3 \mathrm{~min}$. The blood was taken into tubes for blood serum receiving. The serum was kept at $-21^{\circ} \mathrm{C}$ until it was assayed.

All animals were dissected and submitted to routine veterinary examinations. From the present study those bison were eliminated in which the levels of enzymes studied differed significantly from those found in other animals of the same age and sex group. They are not involved in the number of 251 bison discussed in this paper.

The activities of the following blood serum enzymes were determined:

- aldolase (EN 4.1.2.13) FDPA, according to the method of Bruns (1954);

- acid phosphatase (EC 3.1.3.2) AcP and alkaline phosphatase (EC 3.1.3.1) AlP according to the method of Hansen cited by Kokot (1969);

- aspartate aminotransferase (EC 2.6.1.1) AspAT and alanine aminotransferase (EC 2.6.1.2) AlAT according to Reitman and Fränkel (1957).

The results were analysed by the use of the least squares method and the presence of a circannual cycle was estimated by the cosinor circle analysis according to Halberg et al. (1967).

\section{Results}

\section{Aldolase (FDPA)}

Table 1 shows that the mean seasonal activity of FDPA was nearly similar in all groups. But it was higher in young bison than in older ones. Very low values were found in young females in April ( $3.74 \pm 0.96 \mathrm{U})$. In young males the activity was firmly uniform. The highest and lowest values (Table 1) occurred in different months, but all of them were between December and April. The seasonal cyclity was indicated in young females, with the acrophase at the beginning of February (40th day of a year), Fig. 1.

In mature bison the changes were greater, higher in bulls than in cows (Table 1). Monthly changes were similar in both sexes, except in April (maximum in bulls and minimum in cows). The seasonal cyclicity was found in both sexes (Fig. 1), with the acrophase in bulls in the second half of March (82nd day of a year) and in cows ten days later, at the beginning of April (92nd day), with the error ranges 50 and 37 days respectively. So, all three acrophases occurred within only over 50 days of late winter and early spring.

\section{Acid phosphatase (AcP)}

Table 2 shows that the mean seasonal activity of AcP changed in males: from $1.63 \pm 0.09 \mathrm{U}$ in $\mathrm{Gr} .3$ (bulls) to $1.80 \pm 0.09 \mathrm{U}$ in Gr. 1 . In young bison the activity of this enzyme was similar in both sexes in the first 4 months of the year. But in 
Table 1. Activity of aldolase (FDPA) in the blood serum of European bison (in units - U, means \pm $\mathrm{SE}$ ). The highest and lowest values are in boldface. Gr. 1, sexually immature males, $0-3$ years old; Gr. 2, immature females, $0-3$ years old; Gr. 3, mature bulls, over 3 years old; Gr. 4 , mature cows, over 3 years old.

\begin{tabular}{|c|c|c|c|c|c|c|c|c|}
\hline \multirow{2}{*}{ Month } & \multicolumn{2}{|c|}{ Group 1} & \multicolumn{2}{|c|}{ Group 2} & \multicolumn{2}{|c|}{ Group 3} & \multicolumn{2}{|c|}{ Group 4} \\
\hline & $\mathrm{n}$ & $\mathrm{U}$ & $\mathrm{n}$ & $\mathrm{U}$ & $\mathrm{n}$ & $\mathrm{U}$ & $\mathrm{n}$ & $\mathrm{U}$ \\
\hline Jan. & 9 & $8.25 \pm 1.83$ & 9 & $7.60 \pm 1.76$ & 7 & $6.59 \pm 1.21$ & 14 & $5.87 \pm 0.96$ \\
\hline Feb. & 13 & $7.18 \pm 0.94$ & 14 & $6.33 \pm 1.12$ & 5 & $4.11 \pm 0.78$ & 8 & $6.58 \pm 1.28$ \\
\hline Mar. & 21 & $8.13 \pm 0.81$ & 28 & $9.12 \pm 0.77$ & 19 & $7.76 \pm 1.30$ & 15 & $6.35 \pm 0.91$ \\
\hline Apr. & 6 & $6.45 \pm 1.86$ & 3 & $\mathbf{3 . 7 4} \pm 0.96$ & 4 & $9.40 \pm 1.39$ & 4 & $3.29 \pm 1.10$ \\
\hline May & - & - & - & - & - & - & - & - \\
\hline Jun. & - & - & - & - & 6 & $5.23 \pm 1.11$ & 2 & $7.46 \pm 0.23$ \\
\hline Jul. & - & - & - & - & 1 & 2.71 & 1 & 4.07 \\
\hline Aug. & - & - & - & - & - & - & - & - \\
\hline Sep. & 1 & 6.89 & 1 & 3.84 & 3 & $5.18 \pm 1.38$ & 6 & $-5.12 \pm 0.58$ \\
\hline Oct. & - & - & 2 & $8.48 \pm 1.25$ & 1 & 2.03 & - & - \\
\hline Nov. & 4 & $7.04 \pm 0.45$ & 3 & $7.20 \pm 0.05$ & - & - & 1 & 7.23 \\
\hline Dec. & 12 & $7.87 \pm 0.77$ & 7 & $9.49 \pm 0.67$ & 5 & $7.25 \pm 1.05$ & 13 & $8.86 \pm 0.84$ \\
\hline Mean & 67 & $7.65 \pm 0.46$ & 67 & $7.65 \pm 0.46$ & 51 & $6.61 \pm 0.60$ & 64 & $6.57 \pm 0.42$ \\
\hline Cyclicity & & - & & + & & + & & + \\
\hline
\end{tabular}

Table 2. Activity of acid phosphatase (AcP) in the blood serum of European bison (in units - U, means $\pm \mathrm{SE}$ ). The highest and lowest values are in boldface (see Table 1 for futher explanation).

\begin{tabular}{|c|c|c|c|c|c|c|c|c|}
\hline \multirow{2}{*}{ Month } & \multicolumn{2}{|c|}{ Group 1} & \multicolumn{2}{|c|}{ Group 2} & \multicolumn{2}{|c|}{ Group 3} & \multicolumn{2}{|c|}{ Group 4} \\
\hline & $\mathrm{n}$ & U & $\mathrm{n}$ & U & $\mathrm{n}$ & U & $\mathrm{n}$ & U \\
\hline Jan. & 9 & $1.81 \pm 0.27$ & 9 & $2.00 \pm 0.30$ & 7 & $\mathbf{2 . 2 4} \pm 0.30$ & 14 & $1.80 \pm 0.19$ \\
\hline Feb. & 13 & $2.08 \pm 0.27$ & 14 & $1.86 \pm 0.21$ & 5 & $1.28 \pm 0.12$ & 8 & $1.79 \pm 0.22$ \\
\hline Mar. & 21 & $1.69 \pm 0.09$ & 28 & $1.70 \pm 0.14$ & 19 & $1.67 \pm 0.12$ & 15 & $1.82 \pm 0.14$ \\
\hline Apr. & 6 & $1.78 \pm 0.30$ & 3 & $1.76 \pm 0.30$ & 4 & $1.79 \pm 0.40$ & 4 & $1.46 \pm 0.19$ \\
\hline May & - & - & - & - & - & - & - & - \\
\hline Jun. & - & - & - & - & 6 & $1.32 \pm 0.11$ & 2 & $1.31 \pm 0.22$ \\
\hline Jul. & - & - & - & - & 1 & 1.01 & 1 & 1.19 \\
\hline Aug. & - & - & - & - & - & - & - & - \\
\hline Sep. & 1 & 1.15 & 1 & 1.23 & 3 & $1.15 \pm 0.06$ & 6 & $1.25 \pm 0.08$ \\
\hline Oct. & 1 & 1.45 & 2 & $\mathbf{2 . 2 4} \pm 0.91$ & 1 & 1.45 & - & - \\
\hline Nov. & 4 & $1.15 \pm 0.05$ & 3 & $1.31 \pm 0.08$ & - & - & 1 & 1.27 \\
\hline Dec. & 12 & $2.01 \pm 0.29$ & 7 & $1.62 \pm 0.18$ & 5 & $1.73 \pm 0.29$ & 13 & $2.11 \pm 0.28$ \\
\hline Mean & 67 & $1.80 \pm 0.09$ & 67 & $1.76 \pm 0.09$ & 51 & $1.63 \pm 0.09$ & 64 & $1.75 \pm 0.09$ \\
\hline Cyclicity & & - & & - & & + & & + \\
\hline
\end{tabular}


Table 3. Activity of alkaline phosphatase (AlP) in the blood serum of European bison (in units - U, means $\pm \mathrm{SE}$. The highest and lowest values are in boldface (see Table 1 for further explanation).

\begin{tabular}{|c|c|c|c|c|c|c|c|c|}
\hline \multirow{2}{*}{ Month } & \multicolumn{2}{|c|}{ Group 1} & \multicolumn{2}{|c|}{ Group 2} & \multicolumn{2}{|c|}{ Group 3} & \multicolumn{2}{|c|}{ Group 4} \\
\hline & $\mathrm{n}$ & $\mathrm{U}$ & $\mathbf{n}$ & $\mathrm{U} \bullet$ & $\mathrm{n}$ & $\mathrm{U}$ & $\mathrm{n}$ & $\mathrm{U}$ \\
\hline Jan. & 9 & $20.69 \pm 2.26$ & 9 & $18.35 \pm 1.27$ & 7 & $15.92 \pm 1.59$ & 14 & $\mathbf{1 8 . 5 6} \pm 1.06$ \\
\hline Feb. & 13 & $17.69 \pm 0.77$ & 14 & $18.56 \pm 1.43$ & 5 & $17.92 \pm 0.46$ & 8 & $17.39 \pm 0.88$ \\
\hline Mar. & 21 & $16.53 \pm 0.86$ & 28 & $16.66 \pm 0.88$ & 19 & $15.86 \pm 0.93$ & 15 & $15.23 \pm 0.93$ \\
\hline Apr. & 6 & $18.09 \pm 1.63$ & 3 & $17.30 \pm 1.74$ & 4 & $20.97 \pm 3.03$ & 4 & $17.59 \pm 1.71$ \\
\hline May & - & - & - & - & - & - & - & - \\
\hline Jun. & - & - & - & - & 6 & $14.72 \pm 1.01$ & 2 & $11.23 \pm 0.87$ \\
\hline Jul. & - & - & - & - & 1 & 20.51 & 1 & 16.41 \\
\hline Aug. & - & - & - & - & - & - & - & - \\
\hline Sep. & 1 & 12.75 & 3 & 15.43 & 3 & $15.43 \pm 0.59$ & 6 & $16.53 \pm 1.22$ \\
\hline Oct. & 1 & 18.53 & 2 & $11.33 \pm 0.15$ & 1 & 11.18 & - & - \\
\hline Nov. & 4 & $17.44 \pm 0.91$ & 3 & $18.89 \pm 1.33$ & - & - & 1 & 18.90 \\
\hline Dec. & 12 & $14.98 \pm 2.16$ & 7 & $14.90 \pm 3.44$ & 5 & $13.94 \pm 2.61$ & 13 & $7.23 \pm 0.43$ \\
\hline Mean & 67 & $17.21 \pm 0.62$ & 69 & $17.01 \pm 0.61$ & 51 & $16.12 \pm 0.59$ & 64 & $14.83 \pm 0.64$ \\
\hline Cyclicity & & + & & - & & + & & - \\
\hline
\end{tabular}

Table 4. Activity of aspartate aminotransferase (AspAT) in the blood serum of European bison (in units - U, means $\pm \mathrm{SE}$ ). The highest and lowest values are in boldface (see Table 1 for further explanation).

\begin{tabular}{|c|c|c|c|c|c|c|c|c|}
\hline \multirow{2}{*}{ Month } & \multicolumn{2}{|r|}{ Group 1} & \multicolumn{2}{|c|}{ Group 2} & \multicolumn{2}{|c|}{ Group 3} & \multicolumn{2}{|c|}{ Group 4} \\
\hline & $\mathrm{n}$ & $\mathrm{U}$ & $\mathrm{n}$ & $\mathrm{U}$ & $\mathrm{n}$ & $\mathrm{U}$ & $\mathrm{n}$ & $\mathrm{U}$ \\
\hline Jan. & 9 & $62.90 \pm 5.96$ & 9 & $60.99 \pm 7.77$ & 7 & $74.30 \pm 5.90$ & 14 & $55.59 \pm 4.38$ \\
\hline Feb. & 13 & $58.53 \pm 8.07$ & 14 & $52.96 \pm 7.62$ & 5 & $70.13 \pm 3.35$ & 8 & $46.69 \pm 9.12$ \\
\hline Mar. & 21 & $61.39 \pm 4.36$ & 28 & $53.70 \pm 3.43$ & 19 & $55.12 \pm 3.40$ & 15 & $60.70 \pm 4.76$ \\
\hline Apr. & 6 & $64.57 \pm 5.62$ & 3 & $57.97 \pm 8.66$ & 4 & $\mathbf{5 2 . 3 0} \pm 7.30$ & 4 & $69.88 \pm 6.70$ \\
\hline May & - & - & - & - & - & - & - & - \\
\hline Jun. & - & - & - & - & 6 & $82.33 \pm 5.56$ & 2 & $86.00 \pm 2.50$ \\
\hline Jul. & - & - & - & - & 1 & 104.00 & - & - \\
\hline Aug. & - & - & - & - & - & - & - & - \\
\hline Sep. & 1 & 44.80 & 1 & 88.00 & 3 & $77.20 \pm 20.21$ & 6 & $79.07 \pm 10.79$ \\
\hline Oct. & - & - & 2 & $81.00 \pm 3.50$ & 1 & 89.00 & - & - \\
\hline Nov. & 4 & $83.85 \pm 4.08$ & 3 & $86.40 \pm 15.20$ & - & - & 1 & 109.00 \\
\hline Dec. & 12 & $46.10 \pm 6.92$ & 7 & $\mathbf{5 3 . 2 0} \pm 7.56$ & 5 & $58.34 \pm 8.80$ & 13 & $38.85 \pm 3.02$ \\
\hline Mean & 66 & $60.65 \pm 2.90$ & 67 & $58.00 \pm 2.80$ & 51 & $66.43 \pm 2.91$ & 63 & $57.76 \pm 2.93$ \\
\hline Cyclicity & & + & & + & & + & & + \\
\hline
\end{tabular}


the last 4 months of the year activity fluctuated distinctly. The lowest values were in November (Table 2). No seasonal cyclicity was found in young bison.

In mature European bison the changes in activity of this enzyme were also great. The peaks occurred in winter and the lowest values in September (Table 2). The seasonal cyclicity was found in both sexes (Fig. 2), with the acrophase in bulls in the second half of February (58th day of a year) and in cows in the first half of February (40th day of a year). The error ranges were quite big (98 days in bulls and 109 days in cows). The acrophases tended to be earlier than in FDPA activity.

\section{Alkaline phosphatase (AlP)}

Table 3 shows that the mean seasonal activity of AlP changed mostly in mature bison and the lowest mean activity occurred in mature cows. In young bison the activity was similar in both sexes in the first 4 months of the year. But in the last ones the changes were greater, especially in October. The seasonal cyclicity was found in young males (Fig. 3), with the acrophase in mid-January (19th day of a year), but with very wide error range (108 days).

In the mature bison the fluctuations were great and the values changed from month to month (Table 3). The lowest activity occurred in cows in December (7.23 $\pm 0.43 \mathrm{U})$ and the highest one in bulls in April (20.97 $\pm 3.03 \mathrm{U})$. The seasonal cyclicity was found only in bulls (Fig. 3), with the acrophase at the beginning of August (218th day of the year), but the error range reached nearly a half of a year (169 days). So, the difference between the acrophases in studied here young males and mature bulls was more than a half of the year.

\section{Aspartate aminotranferase (AspAT)}

Table 4 shows that the mean seasonal activity of AspAT was higher in males than in females. The highest mean activity was observed in bulls (Gr. 3).

In young bison the changes between January and April were small but in autumn-winter months they were very great. The highest and lowest values were found in two winter months: November and December. The seasonal cyclicity in AspAT activity was found in all groups. In young males (Fig. 4) the acrophase occurred in the second half of January (23rd day of the year) and in females - at the end of August (241st day of the year). The error range was broader in males (126 days) than in females (73 days).

In mature bison the fluctuations were very great, with the lowest and highest values in different months. In bulls the lowest activities were in April and the highest ones in September (except the single specimens). In cows they were in December and in June, respectively.

The seasonal cyclicity was found in both sexes (Fig. 4), with the acrophases in the first days of September in bulls (254th day of the year) and in the last days of August in cows (241st day of the year), with the very narrow error ranges (27 days in bulls and 22 days in cows). So, the acrophases were in 3 groups in the 

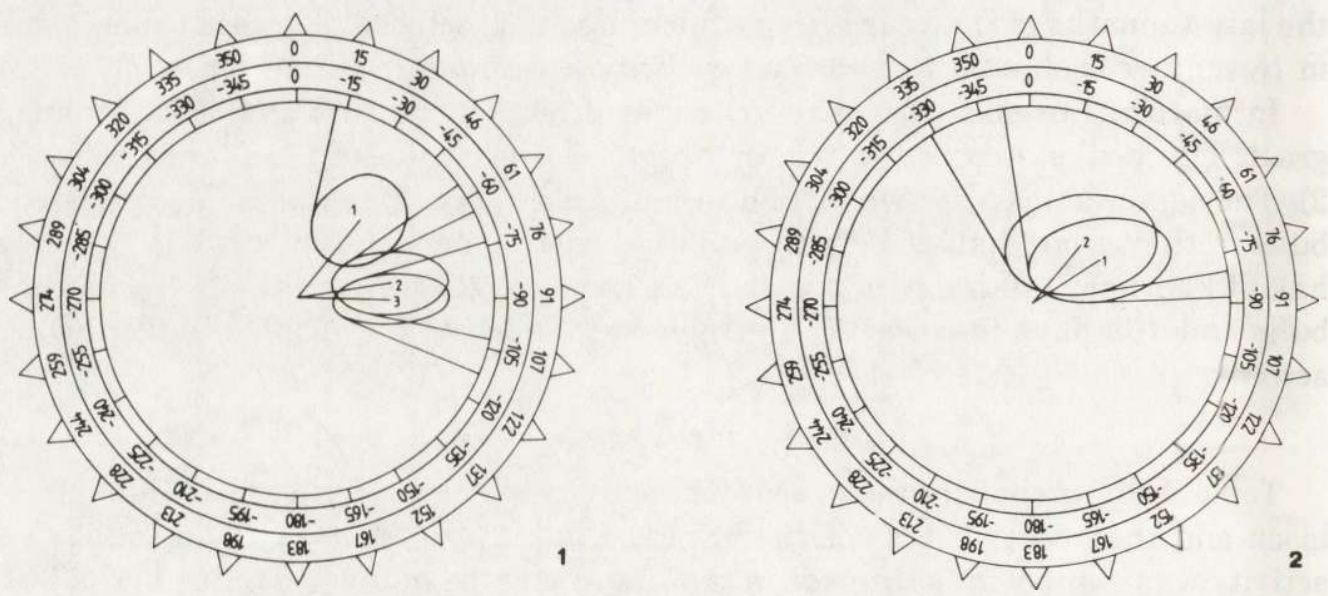

Fig. 1. Cyclicity of aldolase (FDPA) in the blood serum of European bison of groups 2, 3, and 4. Males $(0-3$ years) categorized are in Group 1; females ( 0 - 3 years), as Group 2; mature bulls, as Group 3; mature cows, as Group 4 . The circle covers 365 days a year. The ellipse means error ellipse and dotted lines indicate error range. The straight line indicates the point of the acrophase. $1-$ females $(0-3$ yr), 2 - bulls, 3 - cows.

Fig. 2. Cyclicity of acid phosphatase (AcP) in the blood serum of European bison of groups 3 and 4 (see Fig. 1 for further explanation). 1 - bulls, 2 - cows.
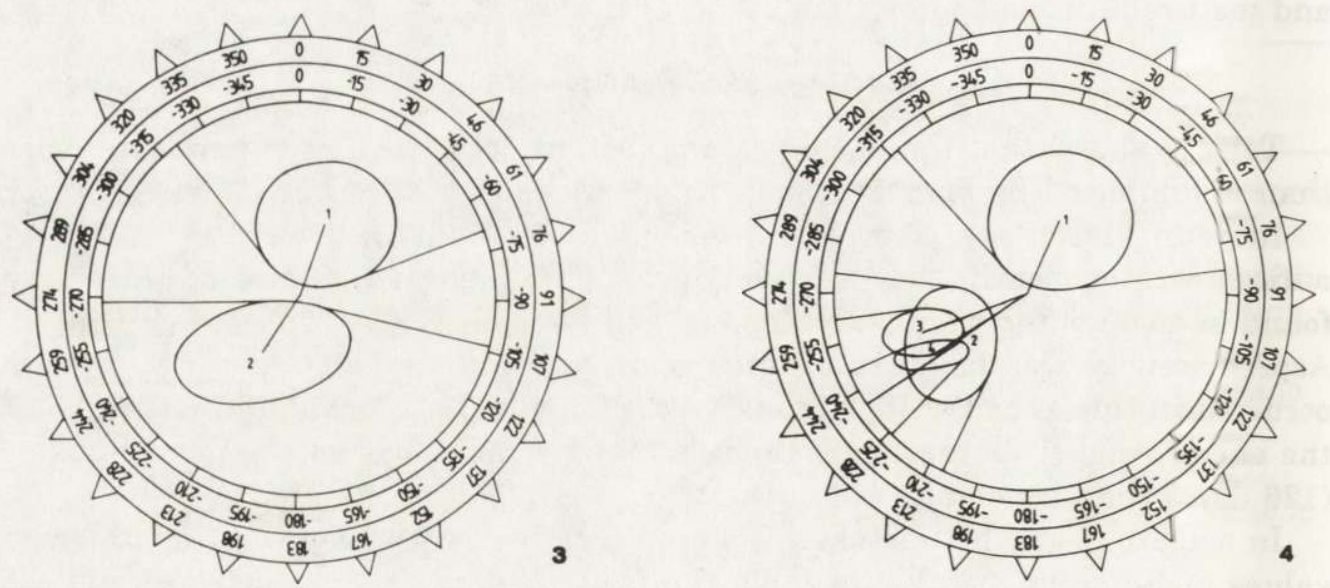

Fig. 3. Cyclicity of alkaline phosphatase (AIP) in the blood serum of European bison of groups 1 and 3 (see Fig. 1 for further explanation). 1 - males $(0-3 \mathrm{yr}), 2$ - bulls.

Fig. 4. Cyclicity of aspartate aminotransferase (AspAT) in the blood serum of European bison of groups $1,2,3$, and 4 (see Fig. 1 for further explanation). 1 - males $(0-3 \mathrm{yr}), 2$ - females $(0-3 \mathrm{yr})$, 3 - bulls, 4 - cows. 
Table 5. Activity of alanine aminotransferase (AlAT) in the blood serum of European bison (in units $-\mathrm{U}$, means $\pm \mathrm{SE}$ ). The highest and lowest values are in boldface (see Table 1 for further explanation).

\begin{tabular}{|c|c|c|c|c|c|c|c|c|}
\hline \multirow{2}{*}{ Month } & \multicolumn{2}{|c|}{ Group 1} & \multicolumn{2}{|c|}{ Group 2} & \multicolumn{2}{|c|}{ Group 3} & \multicolumn{2}{|c|}{ Group 4} \\
\hline & $\mathrm{n}$ & $\mathrm{U}$ & $\mathrm{n}$ & $\mathrm{U}$ & $\mathrm{n}$ & $\mathrm{U}$ & $\mathrm{n}$ & U \\
\hline Jan. & 9 & $13.68 \pm 2.28$ & 9 & $10.77 \pm 2.05$ & 7 & $14.47 \pm 1.61$ & 14 & $11.81 \pm 1.52$ \\
\hline Feb. & 13 & $11.00 \pm 1.07$ & 14 & $9.30 \pm 1.01$ & 5 & $10.40 \pm 1.45$ & 8 & $10.08 \pm 1.72$ \\
\hline Mar. & 21 & $9 . \varepsilon^{n} \pm 1.13$ & 28 & $9.48 \pm 0.98$ & 19 & $8.80 \pm 0.96$ & 15 & $10.89 \pm 1.51$ \\
\hline Apr. & 6 & $9.97 \pm 1.66$ & 3 & $8.00 \pm 2.39$ & 4 & $5.30 \pm 1.10$ & 4 & $6.38 \pm 1.22$ \\
\hline May & - & - & - & - & - & - & - & - \\
\hline Jun. & - & - & - & - & 6 & $8.92 \pm 0.93$ & 2 & $6.85 \pm 1.35$ \\
\hline Jul. & - & - & - & - & 1 & 7.00 & 1 & 6.50 \\
\hline Aug. & - & - & - & - & - & - & - & - \\
\hline Sep. & 1 & 8.50 & 3 & 7.00 & 3 & $8.93 \pm 1.30$ & 6 & $10.10 \pm 0.61$ \\
\hline Oct. & - & - & 2 & $11.50 \pm 0.10$ & 1 & 5.90 & - & - \\
\hline Nov. & 4 & $7.43 \pm 0.49$ & 3 & $\mathbf{7 . 4 0} \pm 1.82$ & - & - & 1 & 8.50 \\
\hline Dec. & 12 & $12.95 \pm 2.16$ & 7 & $15.84 \pm 5.18$ & 5 & $14.02 \pm 2.60$ & 13 & $17.85 \pm 1.79$ \\
\hline Mean & 66 & $10.84 \pm 0.67$ & 69 & $9.97 \pm 0.63$ & 51 & $10.17 \pm 0.66$ & 64 & $11.72 \pm 0.76$ \\
\hline
\end{tabular}

Cyclicity

$-+$

$+\quad+$

Fig. 5. Cyclicity of alanine aminotransferase (AlAT) in the blood serum of European bison of groups 3 and 4 (see Fig. 1 for further explanation). 1 - bulls, 2 - cows.

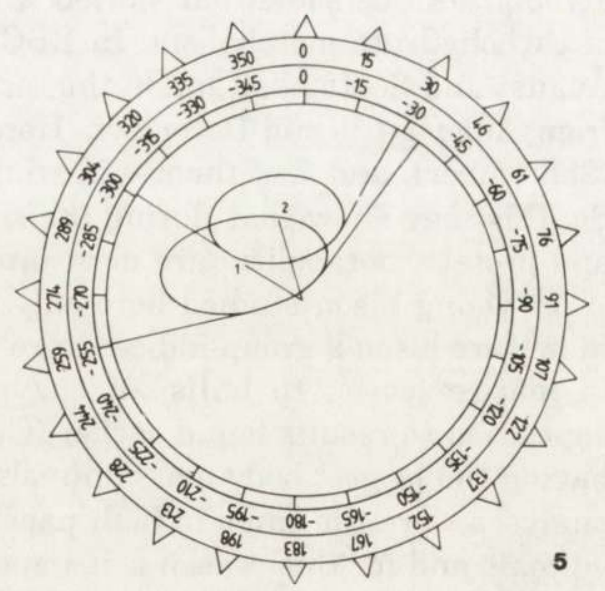

same time, only in young males it was shifted nearly a half of the year. Perhaps the lack of samples in October could change the pattern of cyclicity, in comparison with young females.

\section{Alanine aminotransferase (AlAT)}

Table 5 shows that the mean seasonal activity of AlAT changed in small limits. The mean activity was the highest in mature cows and the lowest in young females. In young bison the activity of this enzyme decreased from January to April in both sexes. In autumn and winter it was changeable. The lowest activities were 
found in November and the highest ones in January (males) and in December (females). No seasonal cyclicity was found in young bison.

In mature bulls and cows the changes were similar, with the lowest values in early spring. The highest values were observed again in January (bulls) and in December (cows).

The seasonal cyclicity was found in both sexes (Fig. 5), with the acrophase in bulls between October and November (304th day of the year) and in cows in mid-December (346th day of the year). The error ranges were quite wide (111 days in bulls and 87 days in cows). So, the acrophases occurred within 42 days, in winter months.

\section{Discussion}

The results obtained in this paper show that the activities of enzymes studied are more cyclic in European bison metabolism than other previous indices studied (Gill 1989a, 1990). This has been stated despite the material was collected for 12 years which could differ more or less one from the other. From 20 group-indices examined here 13 of them showed seasonal cyclicity. But the occurrence of acrophases was somewhat shifted when compared with RBC system and indices of carbohydrate metabolism. In RBC system 7 out of 14 acrophases occurred in August and September and in the second studies -6 out of 9 acrophases occurred from August till mid-December. Here only 3 acrophases were found in autumn (September), and 7 of them - in winter (mid-December till beginning of March). So, this may show that during the coldest months the processes of carbohydrate and protein metabolism are most intensive.

In young bison studied here only 4 group-indices were cyclic, 6 acyclic, when in mature bison 9 group-indices were cyclic, only alkaline phosphatase was acyclic in mature cows. In bulls all enzymes showed seasonal cyclicity. This is in opposition to results found earlier (Gill 1989a) when I stated that the biggest and having the largest body mass animals (bulls) are mostly acyclic. All the statistical analyses were the same in both papers and the material collected from the same animals and for this reason it is impossible to explain why the bulls, showing the cyclicity in enzyme activities have no cyclicity in the peripheral indices of metabolism.

Another fact is very interesting from chronobiological point of view. Patterson et al. (1967) studying changes in some enzymes in cows showed that variation in activity of AlAT was mainly related to pregnancy status and seasonal changes, and the activity of this enzyme was lower during the winter months than in other time (15.75 \pm 1.18 in August, $6.14 \pm 0.40$ m-units $/ \mathrm{ml}$ in December). It concerned only one enzyme. Studying activity of the same 5 enzymes, as in this paper, in racing thoroughbred horses (Szwarocka-Priebe and Gill 1984) we also found changes similar to those found now in European bison. Especially activity of 
AspAT, AlAT and AlP increased from March to July (AlAT to May), later on the activities decreased. We discussed then two factors which pressed on horse metabolism: (a) the length of the days rapidly increased and (b) training of those horses became more intense because the racing season started at the end of April and the horses had to be in good physical condition. The races with the highest selection value were made during the first days of July. From August the horses started in races less frequently and the days became shorter. The activities of ezymes decreased. We put then a question as to whether those changes were seasonal or a result of training.

The European bison studied here were neither trained nor pregnant but showed similar seasonal changes as mentioned above for horses and cows. Only one was common for all those animals - it was the changed day length throughout the year. On the basis of this comparison it is possible to say that the changes in activities of enzymes studied are mainly season-dependant.

Sato et al. (1988) studied AlAT, AspAT and AlP activities in cows $(\mathrm{n}=8)$ on grazing pasture from May 8 th for 21 weeks. All these enzymes tended to elevate during the first 5 weeks of grazing (i.e. to June 12th). Later on activity of AlAT and AlP were kept on the same level and AspAT activity slightly increased. All those changes were insignificant. In European bison activities of the same enzymes increased in autumn and winter moths which have been confirmed by the cosinor circle analysis (Figs 3, 4, and 5). This indicates the influence rather of the approaching winter than the composition of food.

Another fact which confirms the suggestion about seasonal cyclicity is: the data presented now were collected for 12 years. During this time temperatures and humidity changed in the same months of different years, quality of food, fights between bulls or of mature animals with younger ones, the age ranged from several weeks to 3 years in groups 1 and 2, or from 3 to over 25 years in groups 3 and 4 . Only day length was the same, according to season. If in this situation the error range covers in mature bison only 22 to 27 days during the year in AspAT activity or 37 to 50 days in FDPA activity - so this indicates a very distinct regulation of these enzymes used in the European bison metabolism. In other enzymes with cyclic activity the error ranges were broader.

I was also interesting to know if there were distinct differences in the enzyme activities between ages and sexes. From the data presented here it can be seen that in some enzymes the mean seasonal values were very small. In the mean levels of FDPA is seen that in older animals it was lower than in young ones. The differences between young and mature females were significant $(p<0.05)$, which is in agreement with many physiological data concerning the animal age. But in AlP activity, it decreased with numeral progress of groups. Again, the differences between females were significant. The values were higher in young than in mature females. The greatest differences were in AspAT activity: females showed low activity in comparison with males, and the highest values were in bulls. The significant differences were between Gr. 3 (bulls) and Gr. 2 and $4(p<0.05)$. In 
AlAT activity distinct differences occurred in females: the young ones had the lowest and the mature cows - the highest activity, but they were nonsignificant.

Taking into consideration that nearly all acrophases of enzyme activities studied here occurred in winter time and that a very high ratio $\mathrm{T}_{3}: \mathrm{T}_{4}$ was found also in winter (Gill 1989b), the data presented here support the earlier suggestion that the general metabolism in European bison must be distinctly higher in vinter than in summer, which is necessary first of all for thermoregulatory needs.

Acknowledgements: This study was supported by the scientific programme RP.II.12, coordinated by the Jagiellonian University, Cracow, Poland.

\section{References}

Białkowski Z., Saba L., Bis-Wencel H. and Janecki T. 1988. Changes of haematological indices, concentration of total protein, glucose and cholesterol and activity of AP, AspAT and AlAT in blood sera of kids in the first 6 months of life. Med. Wet. 44: 112 - 114. [In Polish with English summary]

Bogin E., Avidar Y., Eyal J. and Sturman H. 1977. Blood levels of enzymes, proteins, metabolites and minerals in healthy bulls. Refuah vet. 34: 19-20.

Brown C. J. and Stallcup O. T. 1985. The relationship of certain serum enzyme levels to feedlot performance of young bulls. Nutrition Reports Intern. 31: $1363-1368$.

Bruns F. 1954. Bestimmung und Eigenschaften der Serumaldolase. Biochem. Z. 325: 156 - 162.

Gill J. 1989a. Seasonal changes in the red blood cell system in the European bison, Bison bonasus L. Comp. Biochem. Physiol. 92A: $291-298$.

Gill J. 1989b. Levels of $\mathrm{T}_{4}, \mathrm{~T}_{3}$ and cortisol in the blood serum of the European bison (Bison bonasus) in the winter period. Comp. Biochem. Physiol. 93A: 567 - 569.

Gill J. 1990. Seasonal cyclicity in carbohydrate metabolism parameters in the European bison, Bison bonasus L. Comp. Biochem. Physiol. 96A: 435 - 439.

Halberg F., Tong Y. L. and Johnson E. A. 1967. Circadian system phase, an aspect of temporal morphology: procedure and illustrative examples. [In: The cellular aspects of biorhythms, Symposium on biorhythms.]. Springer Verl., Berlin: $20-48$.

Kokot F. 1969. [Methods of laboratory experiments used in clinics]. PZWL - State Publ. House for Med., Warszawa: XVI + $1-503$. [In Polish]

Patterson D. S. P., Allen W. M., Berrett S. and Hebert C. N. 1967. Normal variations in three plasma enzymes of the cow. J. Comp. Path. 77: $425-429$.

Peter A. T., Bosu W. T. K., MacWilliams P. and Gallangher S. 1987. Peripartal changes in serum alkaline phosphatase activity and lactate dehydrogenase activity in dairy cows. Can. J. Vet. Res. 51: $521-524$.

Reitman S. and Fränkel S. 1957. A colorimetric method for the determination of serum glutamic oxalacetic and glutamic pyruvic transaminases. Am. J. Clin. Pathol. 28: $56-63$.

Sato H., Kudo Y. and Takeshita K. 1988. Blood metabolite, mineral levels and enzymatic activities in lactating dairy cows on grazing pasture without concentrate feeding. Jpn. J. Vet. Sci. 50: $503-508$.

Szwarocka-Priebe T. and Gill J. 1984. Seasonal enzyme activity changes in two aminotranferases AspAT and AlAT, acid and alkaline phosphatases and aldolase in the serum of Thoroughbred horses during a racing season. Acta Physiol. Pol. 35: 249 - 256.

Received 10 October 1991, accepted 31 July 1992. 